\title{
Effect of ambient seasonal changes in physical and chemical properties of the three types of ground water on the reproductive potential of Oreochromis niloticus reared in concrete ponds
}

\author{
Ashraf M. A. Soliman \\ Limnology Department, Central Laboratory for Aquaculture Research, Abbassa, Abu- \\ Hammad, Sharkia Governorate, Egypt; \\ E-mail: asolimanh@yahoo.com
}

\begin{abstract}
This study was conducted at the intensive fish farm of Arab Fisheries Company (AFC) to investigate the effect ambient seasonal variations of three types of ground water quality (pure aquifer, recycled aquifer water and $50 \%$ mixture of both) on the reproduction of Oreochromis niloticus, Highly significant increase in seed production per pond and newly hatched fry per kilogram of females per season were obtained in spring within the pure aquifer water $(8013.33 \pm 5.89$ seed/pond, $5520.00 \pm 3.62$ seed/ $\mathrm{kg}$ female/season respectively). Highly significant $(\mathrm{p}<0.05)$ differences were observed during the four seasons under ambient condition for the three types of water.

The total fry production and/or relative fecundity of brooders were highly significant $(\mathrm{p}<0.05)$ 280041.25 $\pm 40.3,951.72 \pm 19.33$ respectively under ambient condition of spring in pure aquifer water. In addition, highly significant differences $(\mathrm{p}<0.05)$ were found in water temperature among the studied four seasons.

Although a wide variation in the ambient seasonal changes, the quality of water in reproduction pond were within the optimal range that required for reproduction of $\mathrm{O}$. niloticus.
\end{abstract}

Key words: ground water, water quality, reproduction, Oreochromis niloticus.

\section{INTRODUCTION}

Groundwater provides about twenty percent of the world fresh water supply, which represents about $0.61 \%$ of the entire world water (Columbia Water Center, 2009). Groundwater discharges often have an effect on quality of fish spawning and rearing habitat, and in biological productivity of streams
(Alexander and Caissio, 2003; Gibert et al., 2008,).

In general, recirculation systems recycle about $90-99 \%$ of the daily cultured water, utilize water efficiently, allow for more intensive year-round fry propagation and fish production, and also maintain water quality and temperature within safe and acceptable ranges necessary for fish survival, growth, and 
reproduction (Van Gorder, 1994).

Tilapia is a well known fish of warm-water aquaculture because it has better tolerance than most commonly farmed freshwater fish regarding salinity, water temperature, dissolved oxygen content, and ammonia concentration. Moreover, its easily spawning, wide variety use of natural and artificial feed, rapid growth in warm temperatures and relatively low input costs, as well as, tilapia markets worldwide have expanded rapidly as a consequence of consumers' acceptability to both its good flesh and tasty flavor (Biswas et al., 2005; FAO, 2005).

Tilapia has the capability of breeding continuously throughout the year as long as the environmental conditions are suitable for spawning (LoweMcConnel, 1958). However, in places that are characterized by marked fluctuations in temperature between summer and winter months, the distinguished characteristic of continuous spawning behavior of tilapia is often interrupted by cold temperatures in winter and high temperatures in summer (Fishelson, 1966).

The reproductive potential of tilapia has been reported to be influenced by many factors, including each of temperature (Hyder, 1970), salinity (Chervinski, 1982; Jalabert and Zohar, 1982), food (Bagenal, 1969; Miranova, 1977) population density and social factors (Fryer and Iles, 1972; Allison et al., 1979). The optimum levels of water quality for Oreochromis niloticus reproduction have been determined as $5 \mathrm{mg} / \mathrm{l}$ of dissolved oxygen, total ammonia and $\mathrm{pH}$ concentration ranged from $0.5-2.0 \mathrm{mg} / \mathrm{l}$ and 6.5-7.5 respectively (Ridha and Cruz 1998).

Tilapia male and female broodstock replacement brings about $16 \%$ increase in seed production, when compared with female replacement only with no broodstock exchange (Lovshin and Ibrahim, 1988). Therefore, it is recommended that broodstock be replaced after each period by a fresh batch (Little et al., 1993).

This study was conducted to evaluate water quality effects of ambient seasonal changes on three sources of ground water (pure, recycled aquifer water and the $50 \%$ mixture of both) on the reproductive potential of Nile tilapia (Oreochromis niloticus) in concrete ponds.

\section{MATERIALS AND METHODS}

The present study was implemented in three groups of rectangular concrete ponds with water volume capacity of about 20 cubic meters. Three types of ground water were used (pure aquifer, recycled aquifer water and $50 \%$ mixture of both). The used ground water was considered the main source of irrigation and was pumped through pipeline net that 
innervated for the concrete ponds group that irrigated with pure aquifer water.

Mechanical recirculation system was used. The system was built on a simple technical design which ensures safe and effective function of the mechanical purification of water arriving from the reproduction ponds. In all ponds, water level was maintained at $60-80 \mathrm{~cm}$ according to ambient temperature. Water outlets were built at the bottom of ponds with standby tube as a way to control each of water flow, draining, and cleaning the study ponds. Air was supplied to the study ponds for improving oxygen capacity of fish reproduction ponds. In the design, air-blower machines (5hp each) were used.

Broodstock of Oreochromis niloticus were selected and stocked (30 and 10今) in each pond $\left(20 \mathrm{~m}^{3}\right)$, was set so as to keep the bio-mass of the three pond groups constant while maintaining the sex ratio at $3: 1$ females to males, had average body weight of 284 grams. Males and females were replaced alternatively after each period according to ambient temperature.

The seeds (eggs, yolk -sac fry and swim-up fry) were collected from each pond by removing them from the mouth of the brooding females periodically in accordance with water temperatures that were different between seasons. Seed and sac-fry enumerated volumetrically.
Mean number of seed per pond was calculated by dividing the accrued total number of seed on the total number of brooding females per pond.

Seed production was quantified as number of seeds $\mathrm{Kg}^{-1}$ female and was analyzed for the entire duration. In this sense, the relative or quantum fecundity may be expressed as the number of seed produced per $\mathrm{kg}$ of brooding females (De Graaf et al., 1999).

Ponds were cleaned and water was changed at the time of seed collection. Brooding fish were fed twice daily, 6 days a week (at a range of $1-2 \%$ of their body weight with $40 \%$ protein pelleted fish feed).

Water samples were drawn periodically (weekly) from each pond and were analyzed to determine their chemical and physical characteristics. The work was carried out as follow:

1. Temperature and dissolved oxygen (DO) was measured, twice daily at 6 a.m. and 6 p.m. by using Oxygen-meter (model YSI 58).

2. $\mathrm{pH}$ was measured by using a glass electrode $\mathrm{PH}$-meter (Digital Mini-pH-meter model 55), at 8 am. Transparency was measured by using Secchi disc (SD) according to Boyd (1990).

3. Salinity was measured by using an electrode-conductivity meter, Hach Comparison Apparatus (model Dril 2100) following the method reported by APHA (1985). 
4. Total hardness was measured by titration method according to APHA (1985).

5. Total ammonia concentration was measured by using Hach Spectrophotometer Apparatus (model, DR 2010). The NH3-N was calculated from total ammonia according to Boyd (1990).

\section{Statistical analysis}

Data were analyzed using one and two-way ANOVA for fertilization levels and growth parameters of different fish species as factors. Statistical significance was set at the $\mathrm{P}<0.05$ probability level and means were separated using Duncan's new multiple range test. The software SPSS, version 12 (SPSS, Richmond, USA) was used as described by Dytham (1999).

\section{RESULTS \\ - Temperature $\left({ }^{\circ} \mathrm{C}\right)$}

The highest mean values of water temperature were recorded during summer $(34.10 \pm 0.69$ to $34.50 \pm 1.73^{\circ} \mathrm{C}$ ) all treatments, while the lowest mean values of water temperature were recorded during winter $(23.80 \pm 0.51$ to $24.30 \pm 0.52^{\circ} \mathrm{C}$ ) for different investigated types of water. Highly significant differences $(\mathrm{P}<0.05)$ were recorded in water temperature during the different seasons (Fig 1).

\section{Dissolved Oxygen (DO)}

Dissolved oxygen content of water in reproductive ponds ranged between $4.48 \pm 0.42$ and $4.80 \pm 0.61 \mathrm{mg} / \mathrm{l}$ in aquifer water during autumn and spring; and between $4.87 \pm 0.80 \quad$ and $5.35 \pm 0.53 \mathrm{mg} / \mathrm{l}$ in mixture water during summer and winter; and between $5.73 \pm 0.35$ and $5.99 \pm 1.0$ $\mathrm{mg} / \mathrm{l}$ in recycled water during summer and winter respectively (Fig. 2). The results showed that there were no significant differences ( $\mathrm{p}<0.05$ ) among different seasons for the dissolved oxygen content in the experimental ponds, except aquifer water.

\section{- Hydrogen ion Concentration (pH)}

Mean values of $\mathrm{pH}$ were ranged between $7.13 \pm 0.09$ and $7.25 \pm 0.06$ in aquifer water during summer and winter respectively; and between $7.66 \pm 0.05$ and $8.12 \pm 0.04$ in recycled water during winter and summer respectively; $7.38 \pm 0.05$ and $7.49 \pm 0.08$ in mixture water during spring and summer respectively. It could be observed that there were significant differences $(\mathrm{P}<0.05)$ in hydrogen ion concentration among different seasons for the three investigated types of waters (Fig 3).

\section{- Salinity}

Salinity of aquifers waters (Fig 4) ranged between $2.41 \pm 0.00$ and $2.57 \pm 0.03 \mathrm{~g} / 1$ in winter and summer; and $3.37 \pm 0.02$ and $3.66 \pm 0.12 \mathrm{~g} / 1$ in mixture water during winter and autumn and 2.47 \pm 0.29 and $3.95 \pm 0.25 \mathrm{~g} / \mathrm{l}$ in recycled water during winter and summer.

$\begin{array}{lr}\text { - Total ammonia } & \text { (ionized } \\ + \text { unionized) } & \\ \begin{array}{c}\text { Total ammonia } \\ \text { concentrations in }\end{array} & \text { irrigation }\end{array}$


waters (Fig 5) showed slightly significant differences $(\mathrm{P}<0.05)$ among different seasons for recycled and mixture water $(0.04 \pm 0.00$ to $0.160 \pm 0.00$ and $0.01 \pm 0.00$ to $0.07 \pm 0.02 \mathrm{mg} / \mathrm{l}$ ) during spring and summer respectively. In aquifers water, there were no significant differences among different seasons $(0.00 \pm 0.00$ to $0.01 \pm 0.02$ $\mathrm{mg} / \mathrm{l})$.

\section{- Total hardness}

Total hardness ranged from $1371.33 \pm 35.69$ to $1470.67 \pm 12.72 \mathrm{mg} / \mathrm{l}$ in aquifers water; $1702.67 \pm 20.80$ to $1841.00 \pm 17.10 \mathrm{mg} / \mathrm{l}$ in recycled water; $1571.67 \pm 15.49$ and $1701.67 \pm 67 \mathrm{mg} / \mathrm{l}$ in mixture water during winter and summer respectively. Analysis showed a significant differences $(\mathrm{P}<0.05)$ among seasons for the three types of water (Fig 6).

\section{- Secchi disk (SD)}

It was observed that there were seasonal variations in Secchi disk reading (Fig 7) for irrigation waters ranged from $45.66 \pm 0.33$ to $53.83 \pm 1.16 \mathrm{~cm}$ in aquifers water; $16.33 \pm 0.33$ to $22.50 \pm 0.50 \mathrm{~cm}$ in recycled water during summer and winter respectively and $20.50 \pm 0.28$ and $32.50 \pm 1.10 \mathrm{~cm}$ in mixture water during summer and spring respectively. In general, all values represented high significant differences $(\mathrm{P}<0.05)$ among the different investigated types of water, during different seasons.

\section{- Seed production and Fecundity}

Total number of seed that produced per pond during the ambient condition (Fig 8) indicated that the peak of seed production was during spring especially at aquifers water treatment $\quad(8013.33 \pm 5.89$ seed/pond), followed by mixture and recycled water that were $5106.03 \pm 3.25$ and $2995.83 \pm 1.16$ seed/pond respectively. High significant difference $(\mathrm{p}<0.05)$ in seed production among the three treatments were observed. The lowest number of seeds that produced during winter for aquifer and mixture treatments were $1971.42 \pm 8.20$ and $1316.66 \pm 4.85 \quad$ seed/pond respectively meanwhile, the recycled water provides the lowest production within autumn (1045.68 $\pm 6.05 \mathrm{seed} /$ pond).

Highest newly hatched fry per kilogram of females per season (Fig 9) with the ambient condition were obtained during spring in pure aquifer water followed by summer, autumn and winter $\quad(5520.00 \pm 3.62$, $3718.48 \pm 4.15,1942.96 \pm 2.14$ and $926.66 \pm 4.40 \quad$ seed / $\mathrm{kg}$ female/season) respectively. Meanwhile, the lowest numbers of newly hatched fry per each kilogram of females per season were in the pure recycled water during spring followed by summer, autumn and winter $(2083.43 \pm 3.30, \quad 1820.3 \pm 2.873$, $563.54 \pm 2.38$ and $526.50 \pm 2.88$ seed/ $\mathrm{kg}$ female/season) respectively. The difference were highly significant $(\mathrm{P}<0.05)$. 
Peaks of natural reproductive curve during ambient conditions of different seasons throughout the experimental period were $280041.25 \pm 12.88$, $201233.06 \pm 15.88$, $89585.73 \pm 9.88$ and $53145.29 \pm 6.88$ during spring, summer, autumn, and winter respectively. Highly significant $(\mathrm{p}<0.05)$ differences were found among the total fry produced during the four season under ambient condition of study for the three investigated types of water (Fig 10).

\section{DISCUSSION}

Fresh and low salinity waters were also conserved through the use of brackish water (quite hard) and / or treated recycled water. In the present study, there were no significant differences among different treatments in concerning of various dissolved constituents (i.e. dissolved oxygen, $\mathrm{pH}$, total ammonia and salinity), which were maintained within the acceptable limits these agree with (Balarin and Haller, 1982; Chervinski, 1982 and Ridha and Cruz 1998). The roles of environmental factors in the regulation of reproductive activity in tilapias are not aquifers-understood (Jalabert and Zohar, 1982). Increasing seed production during spring $\left(27.76^{\circ} \mathrm{C}\right)$ may have been stimulated by maintaining temperature within the optimum range for spawning $\left(28.4 \pm 1.0^{\circ} \mathrm{C}\right)$ these in accordance of Rothbard and Pruginin (1975); Beehrends and Smitherman (1983) and $\mathrm{Al}$ Ahmad et al. (1988).
In the present study the increased water temperature in summer and autumn (35.34 and $31.5^{\circ} \mathrm{C}$ respectively) also depressed reproduction and resulted in low seed production rates. A similar observation was reported by Ridha et al. (1985) and Al Ahmad et al. (1988) for Oreochromis spilurus breeders in first and second years of spawning where seed production decreased during August and September. As well as Brummett (1995) reviewed that the environmental factors, which regulate maturation and reproduction in tilapia, and stated that photoperiod, temperature and population density are predictive cues, which effect the onset sexual maturation and reproduction.

Under ambient condition of these Study, increasing of seed production with increasing water temperature during spring to be around $27.76^{\circ} \mathrm{C}$ indicated the important role of water temperature in optimizing seed production in tilapia in accordance with Behrends and Smitherman (1983) and Bautista et al. (1988) who reported a similar effect of water temperature on the spawning of O. niloticus.

Seed production under different types of water (aquifers, recycled and 50\% mixture of both) during four seasons were significantly $(\mathrm{p}<0.05)$ correlated with the fluctuation of water temperature around the year. In addition, the temperature of aquifers water 
showed the best ratios of seed production all over the year. Those accrued findings may be due to the increasing of penetration of light which is very important for ovulation and seed production. The obtained finding was in agreement with that of Brummett (1995).

The very low seed production of females under ambient spawning condition of winter was due to the low temperature $24.03^{\circ} \mathrm{C}$. These finding showed the adverse effect of low temperature on spawning activities of tilapia. The finding was in agreement with that of Rothbard \& Pruginin (1975), and Ridha and Cruz (1998) who stated that tilapia has the capability to start spawning at $22^{\circ} \mathrm{C}$ with the optimum range at $25-29^{\circ} \mathrm{C}$.

\section{REFERENCES}

Al-Ahmad, T. A., Ridha, M., and Al-Ahmed A. A. (1988). Reproductive performance of the tilapia Oreochromis spilurus in seawater and brackish groundwater. Aquaculture, 73: 323-332.

Alexander, M.D. and Caissie, D. (2003). Variability and comparison of hyporheic water temperature and seepage fluxes in a small Atlantic salmon stream. Ground Water, 41 (1): 72-82.

Allison, R.; Smitherman, R. O. and Cabrero, J. (1979). Effect of high density culture and form of feed on reproduction and yield of
Tilapia aurea. In: Advance in Aquaculture (eds. T.V.R. Pillay and W. A. Dill), pp.168-170. Fishing News Books Ltd., Farnham, Surrey.

\section{American Public Health} Association (APHA) (1985). Standard methods for examination of water and wastewater, $16^{\text {th }} \quad$ ed., Washington, D.C.

Bagenal, T. B. (1969): The relationship between food supply and fecundity in brown trout Salmo trutta L. Journal of Fish Biology 1:167-182.

Balarin, J. D. and Haller, R. D. (1982): The intensive culture of tilapia in ponds, raceways, and cages. Pages 267-335 in J.F. Muir and R.J. Robert editors. Recent Advance in aquaculture. West view Press, Boulder, Colorado, USA.

Behrends, L. L. and Smitherman, R. O. (1983): Use of warm water effluent to induce winter spawning of tilapia in temperate climate. In: Proceedings of the First International Symposium on Tilapia Aquaculture. pp. 446454.

Biswas, A. K., Morita, T., Yoshizaki, G., Maita, M. and Takeuchi, T. (2005): Control of reproduction in Nile tilapia Oreochromis niloticus (L.) by photoperiod manipulation. Aquaculture. 243: 229- 239 . 
Boyd, C. E. (1990) Water Quality in ponds for aquaculture. Agriculture Experiment Station, Auburn Univ., Alabama, U.S.A.482 pp.

Brummett, R. E. (1995): Environmental regulation of sexual maturation and reproduction in tilapia. Reviews in Fisheries Science 3: 231-248.

\section{Chervinski, J. (1982):}

Environmental physiology of tilapias. The Biology and Culture of Tilapias. ICLARM Conference Proceeding $7 ;$ 119-128. International Center for Living Aquatic Resources Management (ICLARM). Manila, Philippenes, pp. 119 $-128$

\section{Columbia Water Center (2009): Learn More:} Groundwater". http://http://water.columbia.e $\mathrm{du} /$ ?id=learn_more\&navid=g roundwater/. Retrieved, 9-15.

DeGraaf, J. G., Galemoni, F. and Huisman, A. E. (1999): Reproductive biology of pond reared Nile Tilapia, Oreochromis niloticus (L). Aquaculture Research, 30: 25-33.

Dytham, C. (1999). Choosing and Using Statistics: A Biologist's Guide. Blackwell Science Ltd., London, UK. pp 147.

\section{Food and Agriculture Organization of the United}

Nations (FAO) (2005): FAO Fish Stat plus. Aquaculture Production 1970-2003. FAO, Rome, Italy.

Fishelson, L. (1966): Cichlidae of the genus Tilapia in Israel. Bamidgeh 18:67-80.

Fryer, G. and Iles, T. D. (1972): The cichlid fishes of the great lake of Africa: Their biology and evolution. Oliver and Boyd, Edinburg.641pp (text book).

Gibert, J., Culver D. C., Danielopol D. L., Griebler C., Gunatilaka A., Notenboom J. and Sket, B. (2008): Groundwater ecosystems: human impacts and future management. - In: Polunin, N. V. C. (ed.), Aquatic ecosystems, trends and global prospect. Cambridge University Press, Cambridge, pp. 30-34.

Hyder, M. (1970): Gonadal and reproductive patterns in Tilapia Leucosticta (Teleostei: Cichlidae) in an equatorial lake, Lake Naivasha (Kenya). Journal of Zoology, 162:179-1196.

Jalabert, $B$ and Zohar, Y. (1982): Reproductive physiology in cichlid fishes, with particular reference to tilapia and sarotheradon. The biology and culture of tilapias. ICLARM Conference proceeding 7: 129-140. International center for living Aquatic Resources Management, Manila. 
Little, D. C.; Macintosh, D. J. and Edwards, P. (1993): Improving spawning Synchrony in the Nile tilapia, Oreochromis niloticus (L.) Aquaculture and Fisheries Management 24: 399-405.

Lovshin, L. L. and Ibrahim, $H$. H. (1988): Effects of broodstock exchange on Oreochromis niloticus egg and fry production in net enclosures. Proceedings of the Second International Symposium on Tilapia in Aquaculture. ICLARM Conference Proceedings.15 pp.231-236.

Lowe-McCnnell, R. H. (1958): Observation on the biology of Tilapia nilotica L. in East Africa waters. Revue de Zoolgie de Botanica Africaine 57: 129-170.

Miranova, N. V. (1977): Energy exbinditureon egg productionin youg Tilapia mossambica and their influence of maintenance conditions on reproductive intensity. Journal of Ichthiology, 17: 217-230.

Ridha, M. T. and Cruz, E. M. (1998): Observations on the seed production of the Tilapia Oreochromis spilurus (Gunthur) under different spawning conditions and with different six ratios. Asian Fisheries Society, Manila, Philippines. Asian Fisheries science 10: 201210.

Ridha, M. T. \& Cruz, E. M. (1999): Effect of different broodstock densities on the reproductive performance of Nile tilapia, Oreochromis niloticus (L.), in a recycling system. Aquaculture Research, 30, 203-210.

Ridha, M.; Al-Ahmad, T. A. and Al Ahmad, A. A. (1985): Tilapia culture in Kuwait: spawning experiments 1984, KISR Technical Report 1875. Kuwait Institute for Scientific Research, Safat, Kuwait.

Rothbard, S. and Pruginin, Y. (1975): Induced spawning and artificial incubation of Tilapia, Aquculture, 5: 315321.

Van Gorder, S.D., (1994): Operating and managing water reuse systems. In: Timmons, M.B., Losordo, T.M. (Eds.), Aquaculture Water Reuse Systems: Engineering Design and Management. Elsevier, Amesterdam, the Netherland, pp. 281-306. 


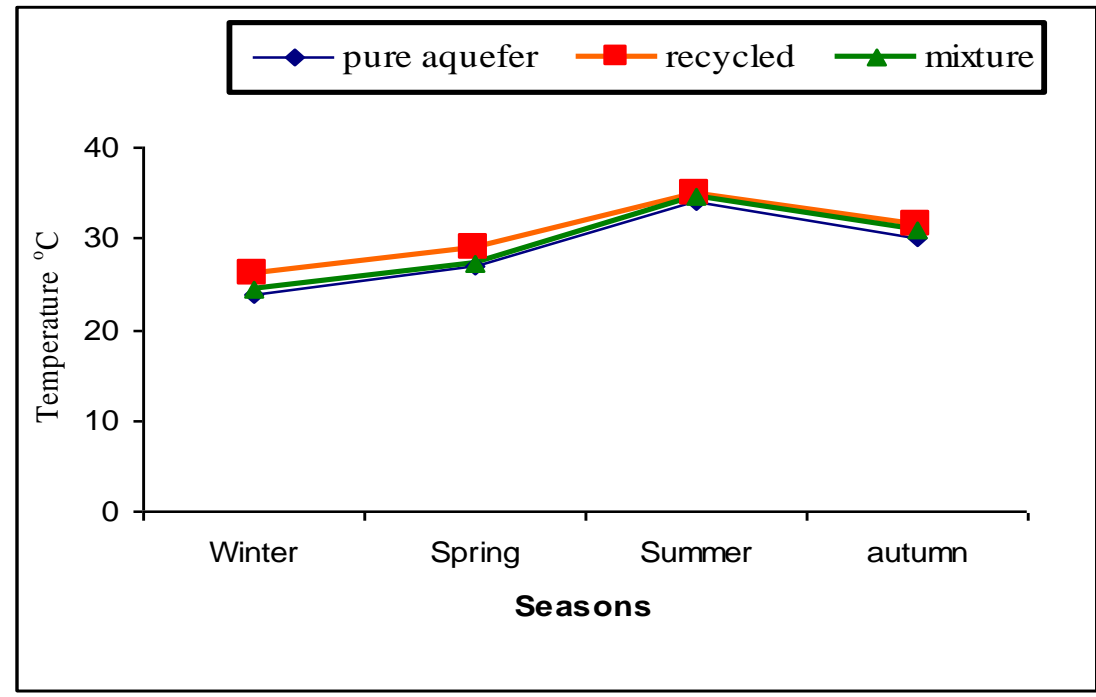

Figure (1): Seasonal variation (mean $\pm \mathrm{SD}$ ) of temperature of pure aquifer, Recycled and $50 \%$ mixture of both inside reproductive ponds of O.niloticus.

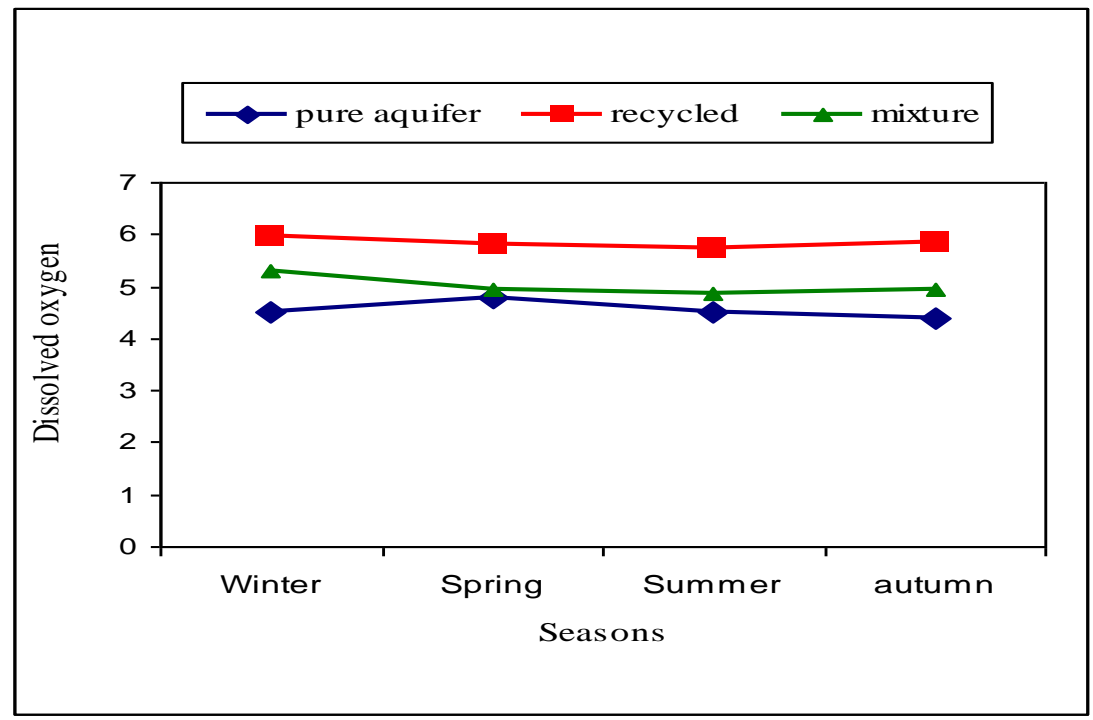

Figure (2: Seasonal variation (mean $\pm \mathrm{SD}$ ) of Dissolved oxygen of pure aquifer, Recycled and 50\% mixture of both inside reproductive ponds of O.niloticus. 


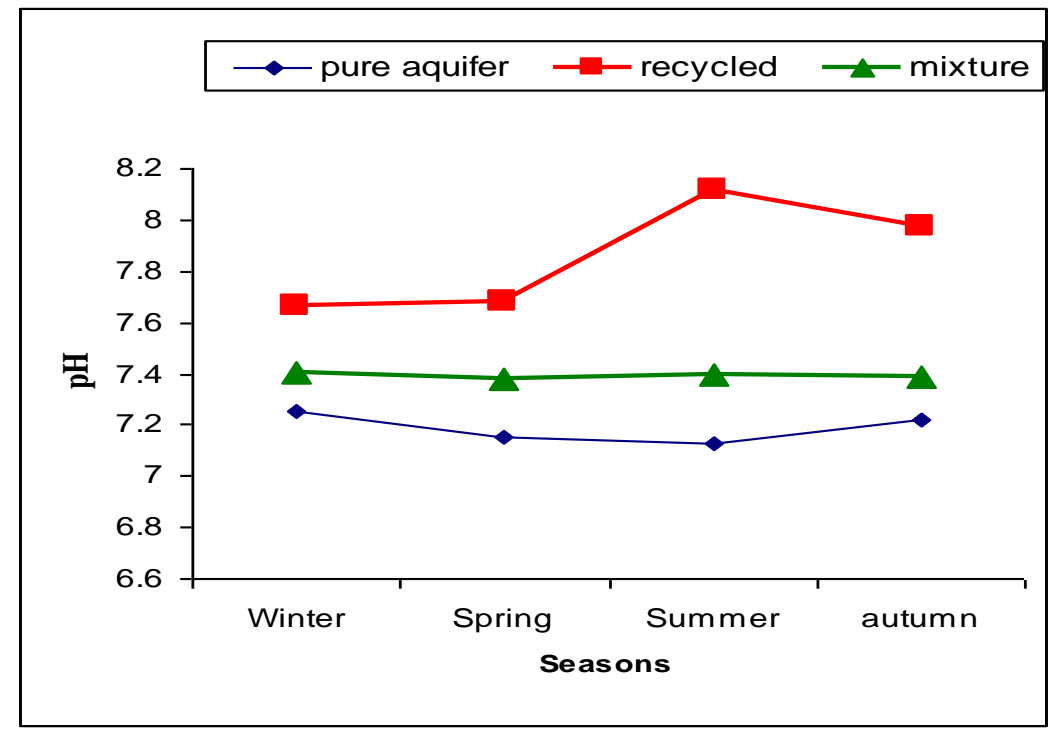

Figure (3): Seasonal variation (mean $\pm \mathrm{SD}$ ) of Hydrogen ion conc. of pure aquifer,Recycled and $50 \%$ mixture of both inside reproductive ponds of O.niloticus.

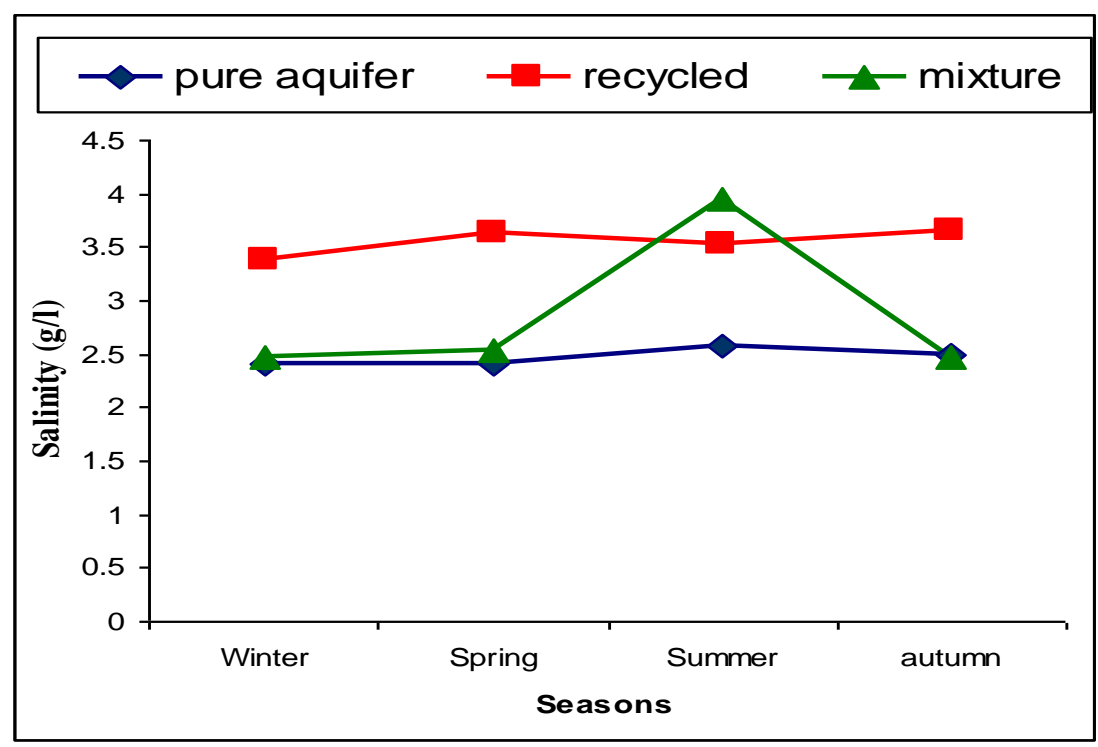

Figure (4): Seasonal variation (mean $\pm \mathrm{SD}$ ) of Salinity of pure aquifer, Recycled and 50\%mixture of both inside reproductive ponds of O.niloticus. 


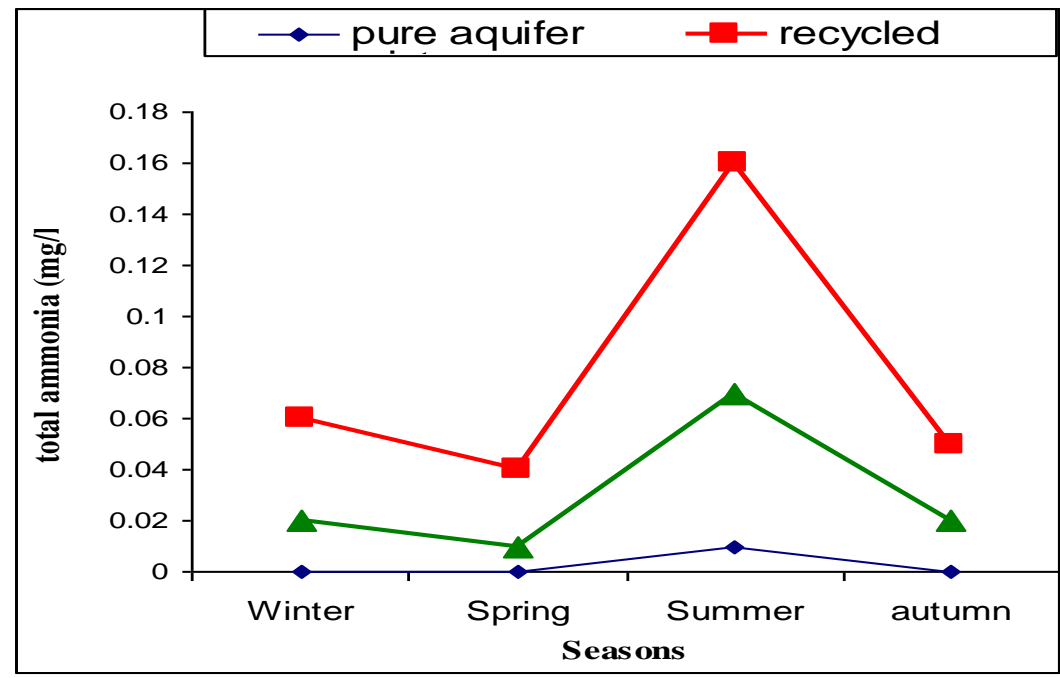

Figure (5): Seasonal variation (mean $\pm \mathrm{SD}$ ) of total ammonia of pure aquifer, Recycled and 50\%mixture of both inside reproductive ponds of O.niloticus.

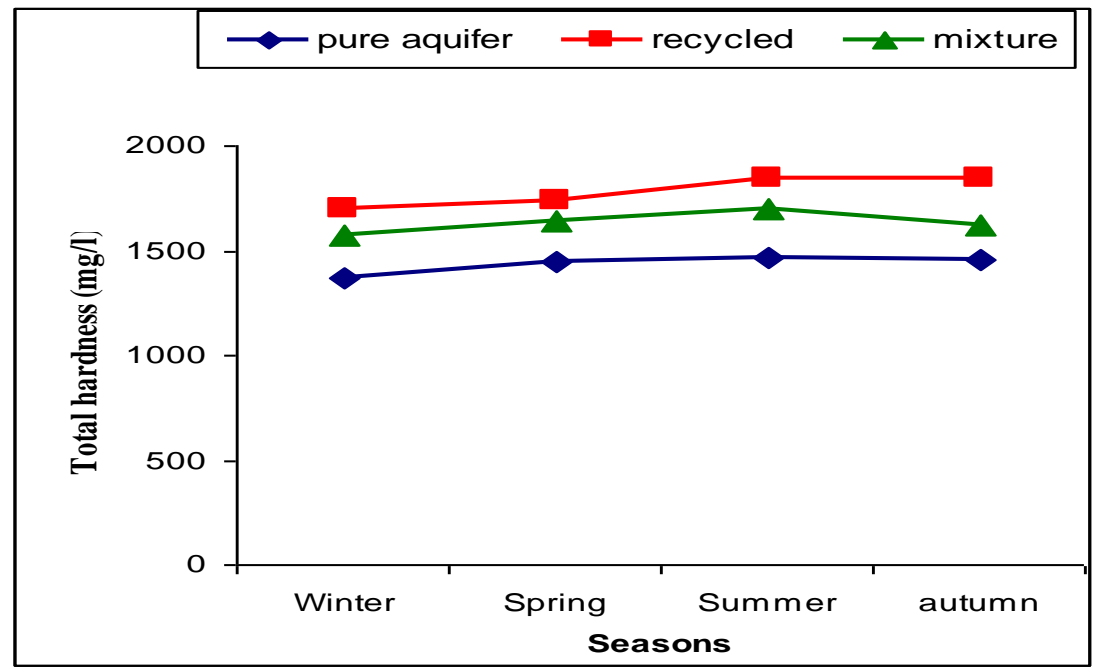

Figure (6): Seasonal variation (mean \pm SD) of Total hardness of pure aquifer, Recycled and 50\% mixture of both inside reproductive ponds of O.niloticus. 


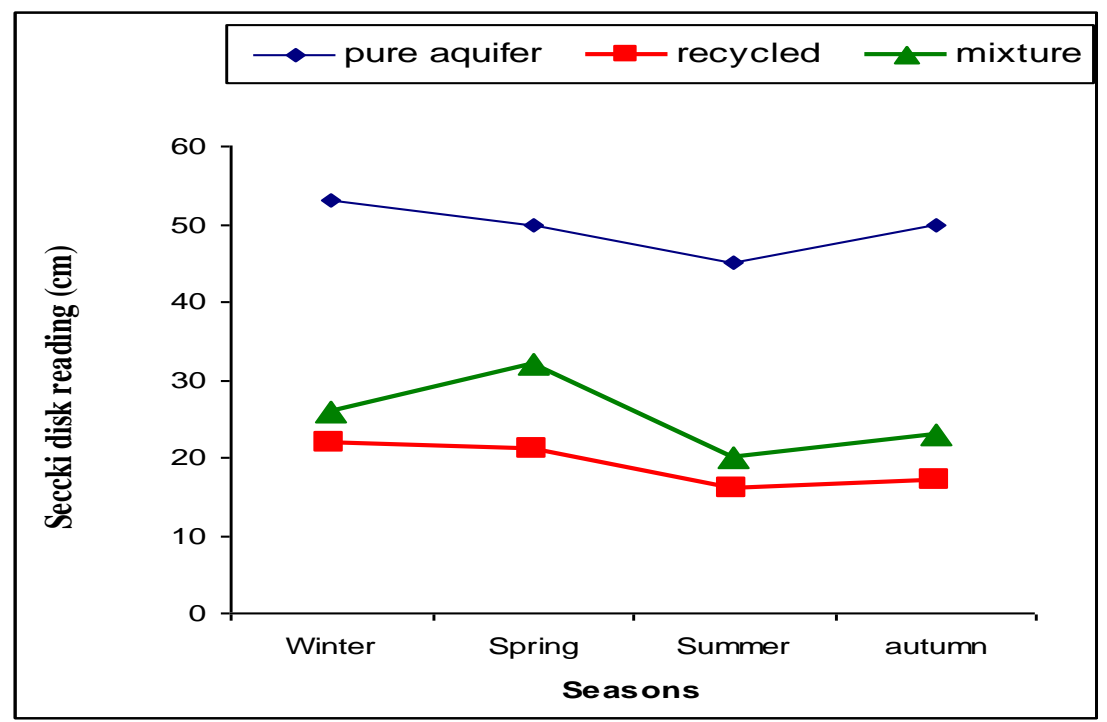

Figure (7): Seasonal variation (mean \pm SD) of Seccki disk reading of pure aquifer, Recycled and 50\% mixture of both inside reproductive ponds of O.niloticus

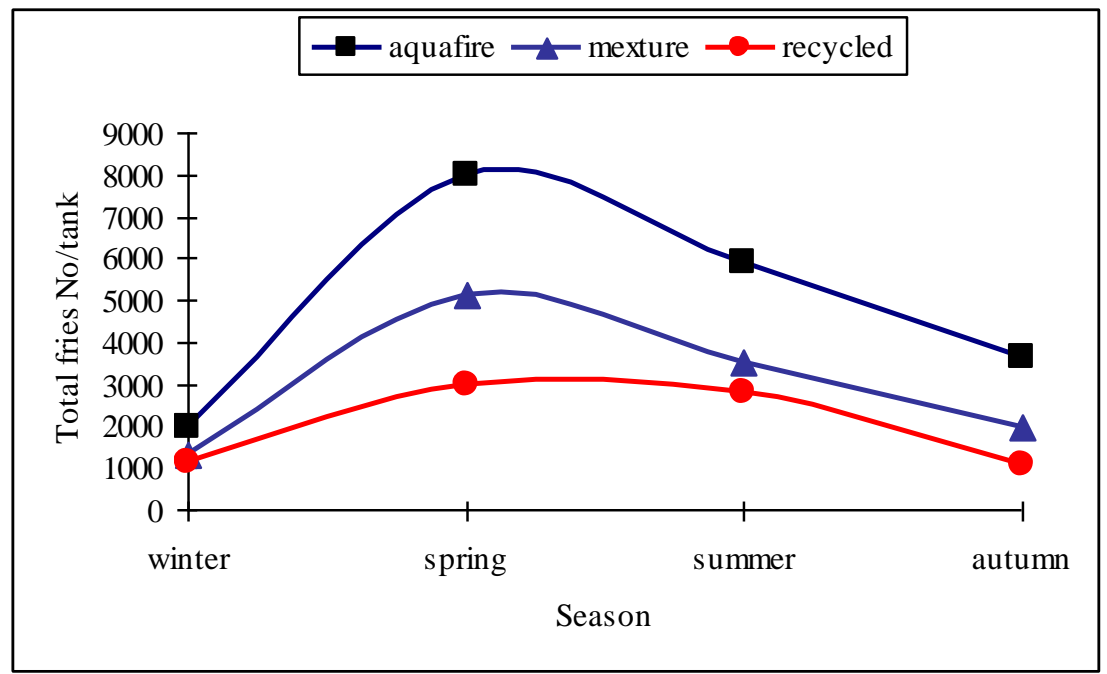

Figure (8): mean (SE) of total fries number collected from each $\boldsymbol{O}$. nilotcus reproduction concrete ponds filled with pure aquifer, recycled aquifer water and the mixture $(50 \%)$ of both . 


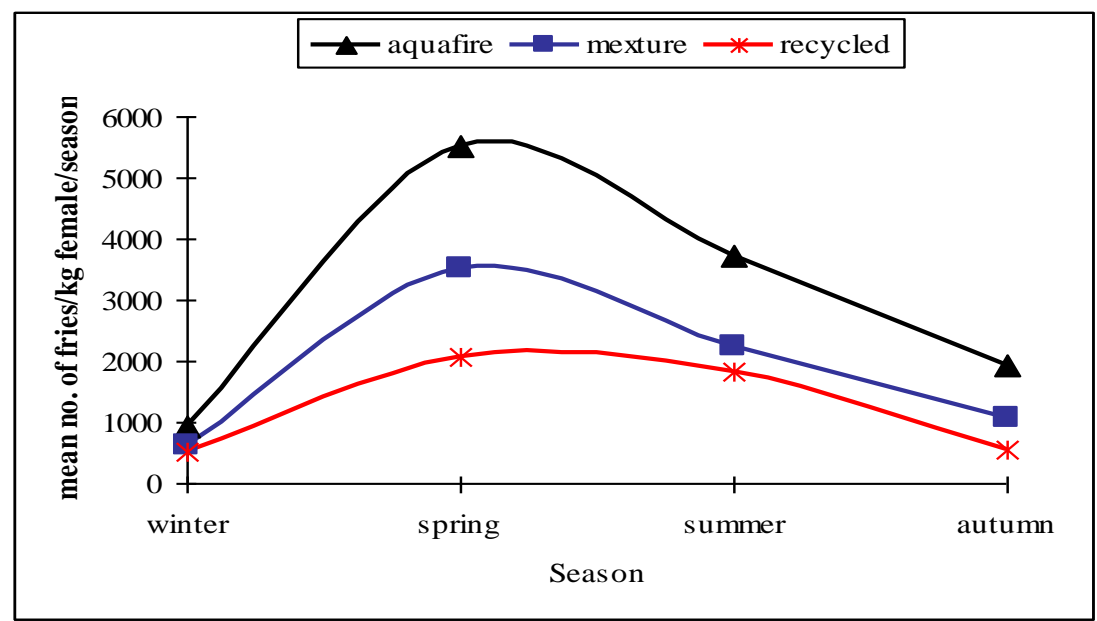

Figure (9): Mean (SE) of total fries number/Kg of brooders collected from $\boldsymbol{O}$. niloticus reproduction concrete ponds filled with pure aquifer, recycled aquifer water and the mixture $(50 \%)$ of both.

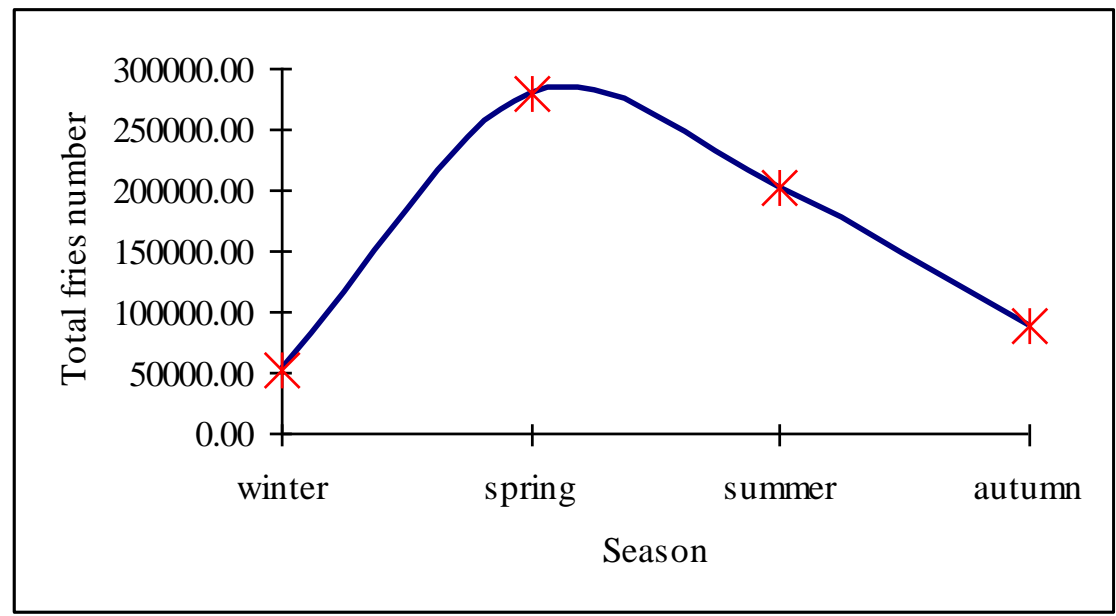

Fig (10): Natural reproductive curve of $\boldsymbol{O}$. niloticus reproduced within concrete ponds filled with pure aquifer, reused aquifer water and mixture $(50 \%)$ of both during four seasons. 


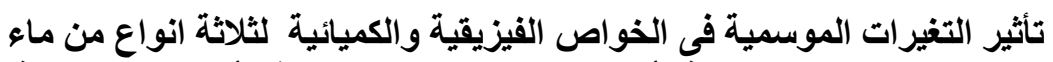

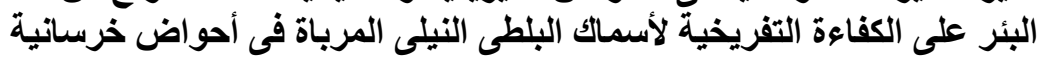

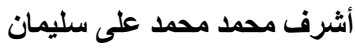 \\ المعمل المركزى لبحوث الثروة السمكية العباسة - قسم الليمنولوجى اليمان

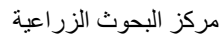

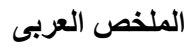

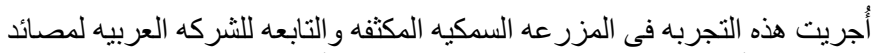

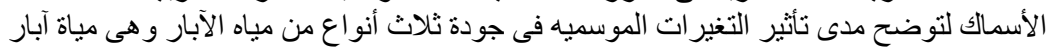

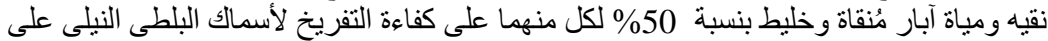

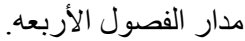

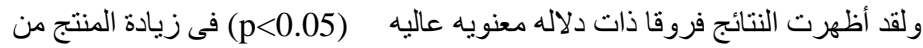

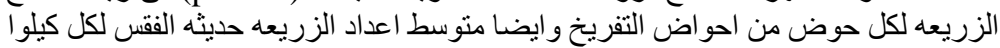

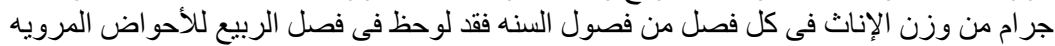

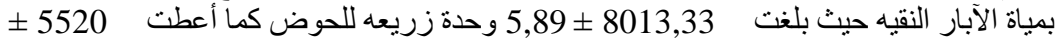

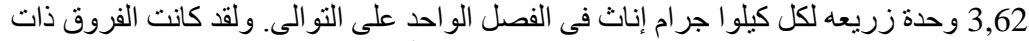
دلاله معنويه (p<0.05) عاليه ملحوظه خلاثلا الفصول الأربعه تحت الظروف المناخيه الطبيعيه

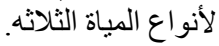

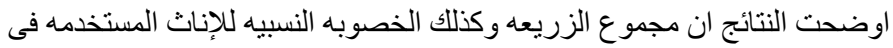

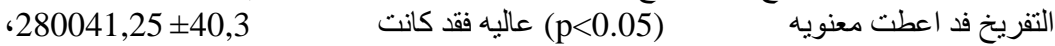
951,52 19,33 على التو الى تحت الظروف الطبيعيه لفصل الربيع فى مياة الآبار النقيه.

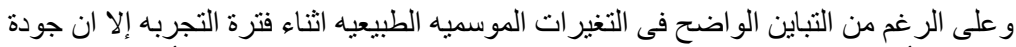

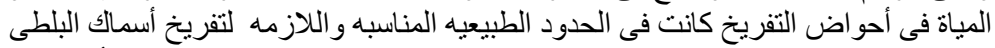

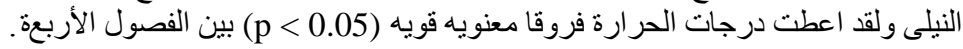

